\title{
Zosteriform dermatoses-A review
}

\author{
L el Hayderi ${ }^{1}$, F Libon ${ }^{1}$, N Nikkels-Tassoudji ${ }^{1}$, A Ruebben ${ }^{2}$, B Dezfoulian ${ }^{1}$ and AF Nikkels ${ }^{1}$ \\ ${ }^{1}$ Departments of Dermatology, CHU of Sart Tilman, University of Liège, Belgium \\ ${ }^{2}$ Dermatology, RWTH, Aachen, Germany
}

\begin{abstract}
The zosteriform distribution of cutaneous lesions is a common disease pattern in dermatology. It describes a unilateral girdle-like distribution restricted to the sensitive nerve territory of a dermatome. Three different pathogenic pathways can lead to a zosteriform pattern. The neural pathway uses the axons of a nerve ganglion for viral transport to a specific dermatome. The arche type is Herpes Zoster (HZ) followed by Zosteriform Herpes Simplex Virus Type (HSV) I infection. The Blaschkoid pathway uses the Blaschko lines that represent embryonic migration patterns, often mimicking a dermatomal distribution, particularly on the trunk. The isotopic pathway defines a dermatosis that exclusively develops on the site of a previously healed $\mathrm{HZ}$ eruption.

Before a zosteriform eruption, a history of prior $\mathrm{HZ}$ guides the diagnosis to the isotopic pathway, mainly represented bygranulomatous reactions followed by, among others, lichen planus, vasculitis and basal cell carcinoma. With no prior history of $\mathrm{HZ}$ recent eruptions orientate towards $\mathrm{HZ}$ and zosteriform $\mathrm{HSV}$, whereas chronic eruptions should primarily evoke cutaneous metastases, principally from breast, ovary and lung carcinoma.
\end{abstract}

This review summarizes the relevant literature and presents a clinical algorithm for the differential diagnosis of zosteriform dermatoses.

\section{Introduction}

Pattern recognition is an important diagnostic tool in clinical dermatology. The zosteriform pattern is defined as an unilateral and belt or girdle-like presentation of a dermatosis along the sensitory nerve territory of a dermatome [1-3].

Although Herpes Zoster (HZ) is the archetype of a zosteriform dermatosis, a large series of other infectious, neoplastic, inflammatory and miscellaneous dermatoses may also present a zosteriform distribution (Table 1).

This paper reviews the three pathogenic mechanisms of the zosteriform pattern and proposes a diagnostic algorithm helping the dermatologist in the differential diagnosis of zosteriform dermatoses.

\section{Materials and methods}

A PUBMED search was performed without restriction of publication date using the following keywords: Varicella Zoster Virus (VZV), varicella, herpes zoster, Herpes Simplex Virus (HSV), herpes simplex, genital herpes, zosteriform, zosteriform dermatoses, segmental, segmental dermatoses, dermatome, dermatomal distribution, isomorphand isotopic dermatoses. This research revealed 220 publications relevant to the subject and included for this review.

\section{Pathogenesis}

Cutaneous diseases presenting a zosteriform distribution answer to 3 different pathogenical pathways.

\section{The neural pathway}

The neural pathway is classically at the origin of HZ [1-3]. The reactivation of latent VZV infection in the neural cell bodies and the satellite cells of the Dorsal Root Ganglia (DRG) results in the replication and synthesis of new viral particles that are transported antidromically via the microtubular system of the axons to the skin.
Once arrived at the free nerve endings between the basal keratinocytes and around the perifollicular free nerve endings, the viral particles egress and are captured by surface receptors on keratinocytes. Once internalized, viral replication leads to the appearance of the cytopathic effect in the host cell, finally leading to its cell death with the liberation of new viral particles. This epidermal cytopathic effect leads to the dehiscence between infected keratinocytes and intra-epidermal blister formation, responsible for the clinically observed vesicular lesions in an unilateral clustered dermatomal distribution. HZ skin lesions occupy a more or less important part of a dermatome, depending on the number of infected axons involved and afflicted by viral reactivation in the DRG. Further cutaneous extension and spreading beyond the dermatomal limits can also be due to the spread of VZV from keratinocyte to keratinocyte, especially in the immunocompromised patient or in the patient with atopic dermatitis or other predisposing skin diseases. In some instances, $\mathrm{HZ}$ can affect more than one adjacent dermatome. Exceptionally, more than one non-adjacent dermatomes or bilateral eruptions are encountered [4]. The unilateral character is not always respected as minor nerve projections frequently extend to the contralateral side [5]. Indeed, it was recently demonstrated that numerous dermatomal maps were inaccurate and subject to significant variations [5]. A novel evidence-based dermatome map (Figure 1) is presented with the most consistent tactile dermatomal areas for each spinal dorsal nerve root found in most individuals. In contrast to previous data, overlap and interindividual variability seem more common than previously thought [5].

Correspondence to: Prof. Dr. A.F. Nikkels, Department of Dermatology, CHU du Sart Tilman, University of Liège, B-4000, Liège, Tel: +32 4366 7232; Fax: +32 4366 7234; E-mail: af.nikkels@chu.ulg.ac.be

Key words: herpes simplex virus; varicella zoster virus, zosteriform; metastases, lichen planus, isotopic

Received: July 28, 2015; Accepted: August 21, 2015; Published: August 24, 2015 
Table 1. Benign and malignant tumoral, inflammatory and miscellaneous zosteriform dermatoses.

\begin{tabular}{|c|c|}
\hline Benign and malignant tumors & Inflammatory dermatoses \\
\hline Primary cutaneous tumors & Drug reactions \\
\hline $\begin{array}{l}\text { - Angiosarcoma } \\
\text { - Kaposi's sarcoma } \\
\text { - Squamous cell carcinoma } \\
\text { - primary cutaneous T-cell lymphoma } \\
\text { - primarycutanoues B-cell lymphoma }\end{array}$ & $\begin{array}{l}\text { Lichen planus } \\
\text { Lichen aureus } \\
\text { Lichen sclerosus } \\
\text { Darier's disease } \\
\text { Pityriasislichenoides } \\
\text { Morphea }\end{array}$ \\
\hline Cutaneous metastases & $\begin{array}{l}\text { Granuloma annulare } \\
\text { GVHD }\end{array}$ \\
\hline \multirow{10}{*}{$\begin{array}{l}\text { - Gastrointestinal cancer } \\
\text { - Breast carcinoma } \\
\text { - Endometrial cancer } \\
\text { - B-cell chronic lymphocytic leukemia } \\
\text { - Hodgkin's lymphoma } \\
\text { - Nodal T-cell lymphoma } \\
\text { - Ovary carcinoma } \\
\text { - Pulmonary cancer } \\
\text { - Leiomyoma } \\
\text { - Mesothelioma } \\
\text { - Renal carcinoma } \\
\text { - Melanoma } \\
\text { - Prostate } \\
\text { - Merkel cell carcinoma }\end{array}$} & Miscellaneous \\
\hline & Melanocytic hamartomas \\
\hline & Connective tissue hamartomas \\
\hline & Epidermal hamartomas \\
\hline & Perforating collagenosis \\
\hline & Porokeratosis \\
\hline & $\begin{array}{l}\text { Pigmentary disorders } \\
\text { Progressive cribriform and zosteriform } \\
\text { hyperpigmentation }\end{array}$ \\
\hline & Spitz nevi \\
\hline & $\begin{array}{l}\text { Arteriovenous malformations } \\
\text { Unilateral dermato malcavernous } \\
\text { hemangiomatosis }\end{array}$ \\
\hline & Transient acantholyticdermatosis \\
\hline Eccrinespiradenoma & \\
\hline Neuroma & \\
\hline Trichoepitheliomas & \\
\hline
\end{tabular}
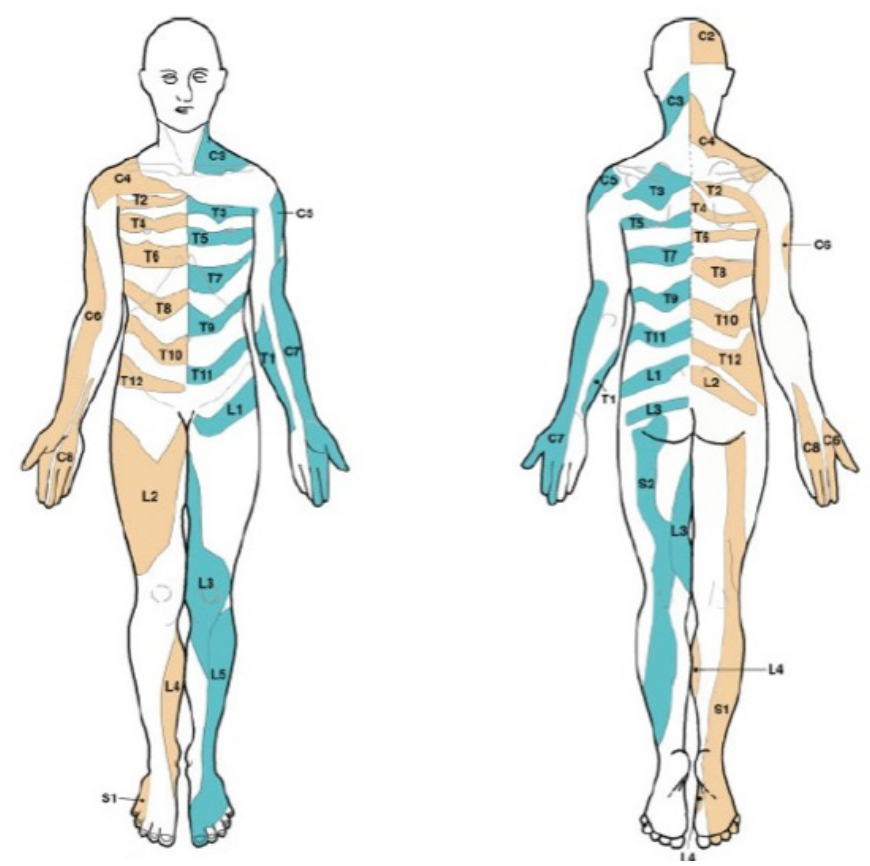

Figure 1. Evidence-based dermatome map according to Lee et al. [5].

HSV type I and type II also use the neural pathway. In fact, these other alpha-herpesviruses share a number of identical features with $\mathrm{VZV}$, in particular the epidermo-neurotropism [6-18].

The nerve fibers may also function as anatomical substrate for perineural progression of breast cancer cells and Squamous Cell Carcinoma (SCC) cells, probably related to the neurotropic character of these cells. SCC presents neurotropism through its ectodermal origin $[19,20]$. The presence of Neural Cell Adhesion Molecules (N-CAM) does however not always equal neurotropism in SCC. Probably, other cell surface markers may also confer neurotropism [21,22]. Schwannomas can also follow a nerve distribution, called segmental Schwannomas [23]. Multiple palisaded encapsulated neuromas are a rare benign neural skin tumor that also may exhibit a dermatomal pattern [24]. Furthermore, this pattern can be found in OTA naevi, with melanocytic progression along the nerve fibers. In general, neoplastic growths deriving from cells originating from the neurectodermal crest are more prone than other cell types to present zosteriform metastatic migration.

\section{The Blaschkoid pathway}

Embryonic migration of cutaneous cell populations is directed by ectodermal development patterns. During embryogenesis, when the presence of the primitive line gives the embryonic disk bilateral symmetry, precursory cells start to proliferate on the midline and grow in transversal direction from this line. These migration patterns can become visible when genetic mosaicism occurs, ie two or more genetically distinct cell populations derived from a genetically homogeneous zygote.These lines are called Blaschko lines and represent the boundaries between genetically normal and abnormal cell populations [25]. This phenomenon typically affects the keratinocytes, fibrocytes and melanocytes, etc. Furthermore, these patterns change from one cell type to another andalso depend on the timing of the occurrence of the mosaicism. Five types of Blaschko lines are distinguished includingthe classic (narrow and broad), checkerboard, phylloid, patchy and lateralization patterns [25].

The classic type is the most common with patterns in a $\mathrm{V}$ shape on the back and in an S shape on the antero-lateral portion of the trunk [26-28]. This classic pattern can further be divided into narrow (1a) and broad (1b) bands. This distribution pattern is often difficult to distinguish from dermatomes, in particular on the trunk.

\section{The isotopic pathway}

The isotopic phenomenon is defined as a dermatosis that only develops and remains restricted to the site of a previous other healed dermatosis [29-31]. The most typical examples are dermatoses occurring on the site of healed previous HZ, explaining the zosteriform distribution. Granulomatous reactions are the most commonly encountered.

The exact origin of the isotopic pathway remains unclear but it may be related to VZV-induced alterations in epidermal and dermal components of the skin immune system, favoring the occurrence of some dermatoses without expressing themselves on non-previously involved skin.

Several hypotheses have been advanced. A transient immune silencing may be suspected as demonstrated by the sparing of primary cutaneous T-cell lymphoma (pCTCL) extension on the site of previous $\mathrm{HZ}$ involving the left T8 dermatome. Immunohistochemical analysis of a clinically uninvolved patch revealed absence of CD1a+ cells in the epidermis, consistent with loss of Langerhans cells (LC) in the areas spared by pCTCL. There was no loss of LC in areas affected by pCTCL. This is an unusual inhibition of pCTCL by a prior viral infection. The loss of LCs in the clinically spared skin suggests a role 
for LC in the epidermotropism of lymphocytes in PCTCL [32]. The same phenomenon is observed with the avoidance of allergic contact dermatitis lesions at the site of florid $\mathrm{HZ}$, suggesting an inhibition or an incapacitating action of VZV on the epidermal LCs conducting to a transitory silencing of the antigen presenting capacities of the cutaneous immune system [33].

Another hypothesis suggests a delayed type hypersensitivity reaction to the persistence of residual viral glycoproteins in the dermis [34]. In recently resolved cases of HZ, VZV DNA could still be retrieved from granulomatous skin reactions by PCR [35-37]. In cases of granulomatous reactions occurring later after the resolution of $\mathrm{HZ}$, no viral DNA was evidenced [38-43]. In granulomatous reactions affecting elderly previous $\mathrm{HZ}$ sites, the presence of the gE and gBVZV envelope glycoproteins, highly resistant to enzymatic degradation, was evidenced by immunohistochemistry, whereas viral DNA was not found [41]. Not only VZV antigens and DNA could be found in zosteriform granulomatous reactions but also HSV [41,44]. As there is no residual viral DNA in the granulomatous reactions developing later after the resolution of $\mathrm{HZ}$, the treatment rather requires topical corticosteroids [41] or intralesional corticosteroids than antivirals [45].

A third hypothesis is a local neuro-immune deregulation set off by alphaherpesvirus-induced lesions of dermal sensory nerve fibers [46].

Other dermatoses than granulomatous reactions are far less common and their pathogenesis remains largely unclear (Table 2).

\section{The algorithm of the differential diagnosis of zosteriform dermatoses}

The first distinction is to determine whether the patient has previously presented $\mathrm{HZ}$ or not at that particular site.

\section{Patient with a previous history of $\mathrm{HZ}$ at the site of the zosteriform eruption}

If the patient presents a zosteriform dermatosis that is restricted to the site of a previous $\mathrm{HZ}$ eruption, the differential diagnosis has to be made among the zosteriform isotopic responses (Table 2) [26,30,31]. The site of healed $\mathrm{HZ}$ is the most usual area to develop isotopic responses. Indeed, in a case-series review, 52 out of 58 cases of isotopic responseswere localized on healed sites of previous HZ (30). Relatively

Table 2. Differential diagnosis of isotopic-zosteriform dermatoses.

\section{Granulomatous reaction}

(granulomatous dermatitis, granulomatous vasculitis, sarcoidal granuloma,

granulomatous folliculitis, granuloma annulare, granuloma formation, tuberculoid granuloma)

Lichen sclerosus

Lichen planus

Pseudolymphoma

Morphea

Dermatophytoses

(Candida albicans, Epidermophyton floccosum, Trichopyton mentagrophytes)

Eruptive keratoacanthoma

Cutaneous lymphoid infiltrates of B-cell chronic lymphocytic leukemia

Primary cutaneous B-cell lymphoma

Cutaneous metastases of angiosarcoma

Skin metastases of breast carcinoma

Melanoma

Squamous cell carcinoma

Basal cellcarcinoma

Lymphoma, leukemia cutis

Kaposi's sarcoma

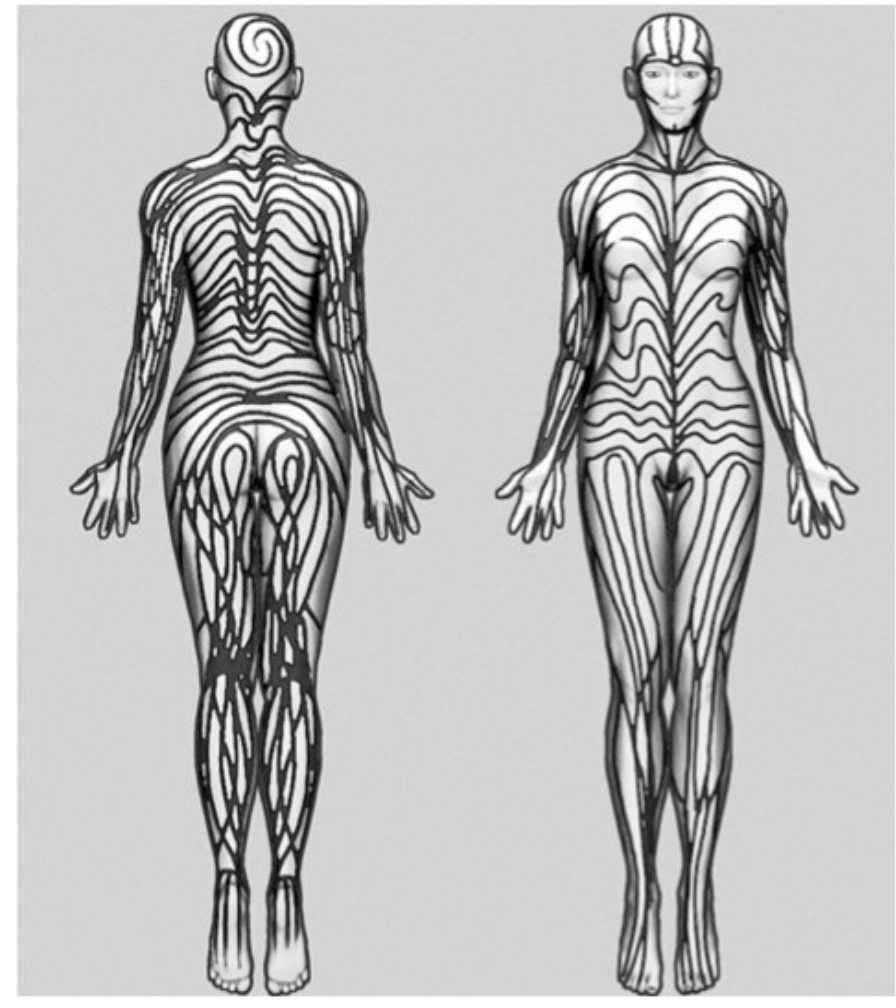

Figure 2. Blaschko lines, with a zosteriform pattern on the trunk.

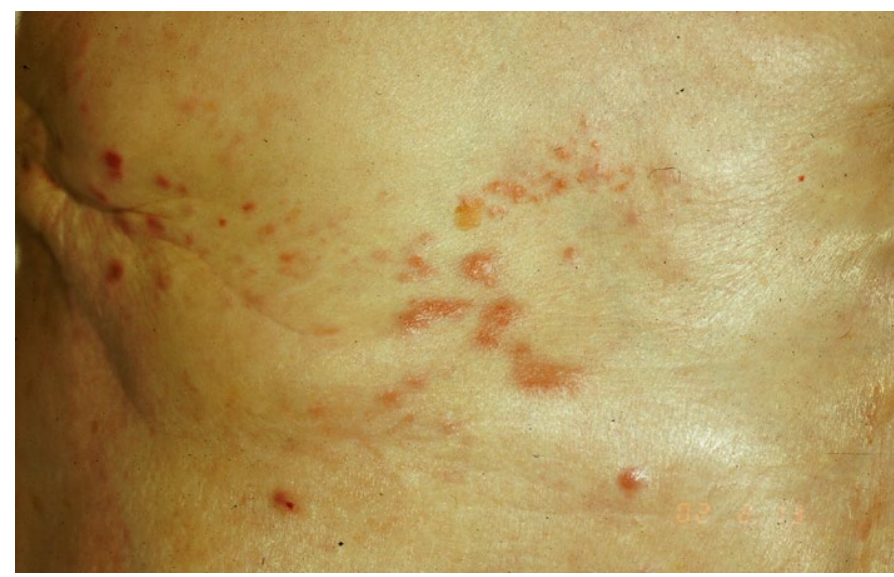

Figure 3. Post zoster granulomatous vasculitis affecting the latero-anterior T7,T8

recently healed $\mathrm{HZ}$ sites are particularly prone to develop a large series of various granulomatous reactions, includinggranulomatous dermatitis, granulomatous vasculitis (Figure 3), sarcoidal granuloma, granulomatous folliculitis, granuloma annulare, granuloma formation and tuberculoid granuloma [34,47-73].

In the event of an isotopic-zosteriform eruption on an more ancient site of previous $\mathrm{HZ}$, cutaneous metastasis of a variety of internal malignancies should be considered as first hypothesis. Breast carcinoma cutaneous metastases (15/26 cases) are the most frequently observed, probably linked to the initial localization of breast cancer [30]. Squamous cell carcinomas, basal cell carcinomas, primary cutaneous lymphomas [74,75], leukemic infiltration (particularly B-cell) [76], melanoma and melanoma cutaneous metastases, angiosarcoma [77,78], basosquamous carcinomas, Kaposi's sarcoma and Bowen's disease are 
less frequent (Table 2) [30,31]. Inflammatory dermatoses restricted to ancient $\mathrm{HZ}$ sites are more exceptional and comprise lichenoid GraftVersus-Host-Disease (GVHD) [79-81], morphea [82,83] and localized chronic urticaria [84]. Infectious dermatoses are even more rare and include fungal granulomas [85], dermatophytosis [86] and molluscum contagiosum [87] (Table 2).

Another complication that can precisely occur at the site of healing or healed $\mathrm{HZ}$ is zosteriform keloid formation. In particular patients with a black skin are prone to this complication (Figure 4) [88-90]. The presence of VZV DNA in FXIIIa positive dermal dendrocytes might lead to a dysfunction, hence altering their important role in the scarring process $[38,41]$. As observed during other dystrophic scarring processes, comedo formation may be observed [91] and even cutaneous calcification in a zosteriform distribution [92].

\section{Patient without a previous history of $\mathrm{HZ}$ at the site of the zosteriform eruption}

If the zosteriform eruption is recent ( $<10-14$ days), $\mathrm{HZ}$ is the most likely diagnosis (Figure 5). However, zosteriform HSV infections (Figure 6) are encountered in up to $25 \%$ of the cases initially diagnosed as $\mathrm{HZ}$ on a clinical base, particularly in the facial dermatomes [618,93]. The immunohistochemical distinction between HSV and VZV can readily and rapidly be performed on a Tzanck smear, with a high specificity and sensitivity [2]. This distinction is important in terms of dosing regimens, different for HSV and VZV infections [2].

If the eruption is more longstanding ( $>14$ days), zosteriform primary skin cancers, including predominantly SCC (Figure 7), but also Kaposi's sarcoma, angiosarcoma, pCTCL (Figure 8) and primary

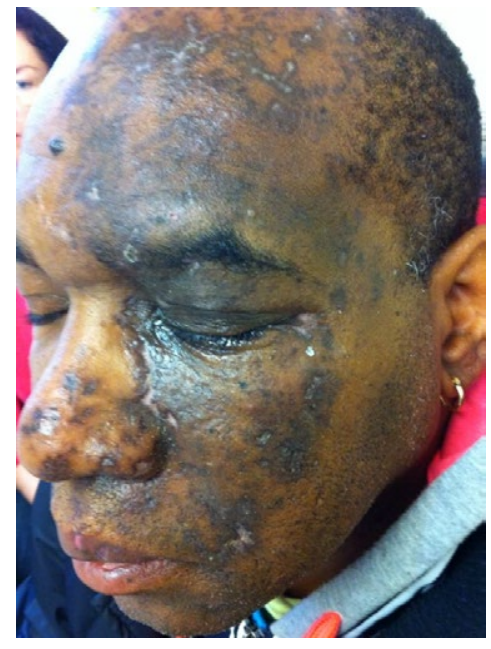

Figure 4. Severe zosteriform scarring after $\mathrm{HZ}$ of the V2 and V3 dermatomes.

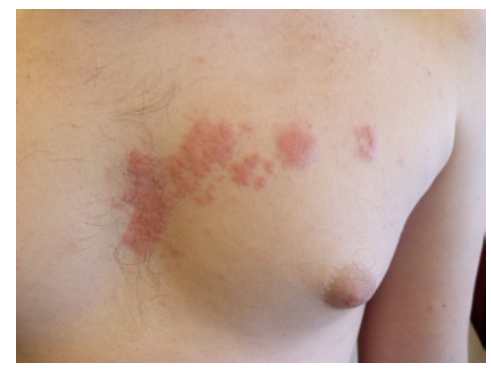

Figure 5. HZ of the anterior aspect of $\mathrm{T} 2$.

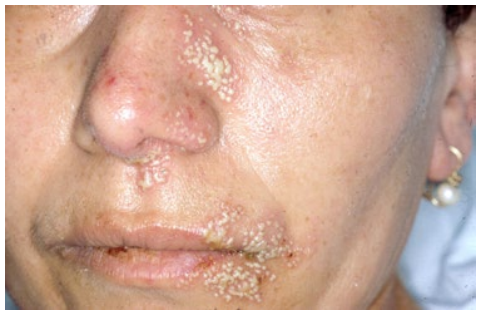

Figure 6. Zosteriform HSV type I infection affecting V2 and V3.

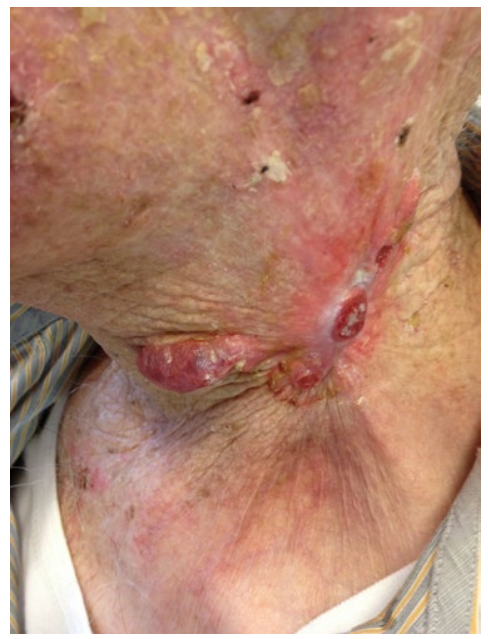

Figure 7. SCC and cutaneous metastases of SCC (Lateral aspect of C3).

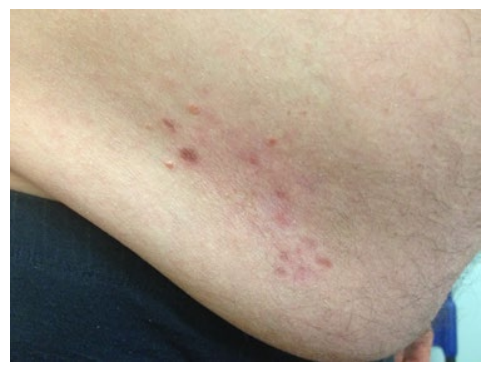

Figure 8. pCTCL involving the frontal aspect of T12.

cutaneous B-cell lymphoma (pCBCL)should primarily be considered [30,31,78,94-109]. Zosteriform cutaneous metastases of internal malignancies have also to be discarded [110-165], in particular in the elderly patient with an abnormal long duration and a not precisely dermatomal distribution as well as in patients with a history of cancer. Cutaneous metastases of breast cancer (Figure 9) are the most frequently described, probably due to its primary localization in the T3 and T4 dermatomes. Other less frequently described cutaneous metastases are described, listed in term of decreasing number of publications; melanoma $(\mathrm{n}=10)$, leiomyoma $(\mathrm{n}=8), \mathrm{B}$-cell chronic lymphocytic leukemia $(n=6)$, gastrointestinal cancer $(n=5)$, renal cancer $(n=4)$, pulmonary cancer $(n=3)$ ovary cancer $(n=2)$, mesothelioma $(n=1)$ endometrial cancer $(\mathrm{n}=1)$, Hodgkin's lymphoma $(\mathrm{n}=1)$, nodal T-cell lymphoma $(n=1)$, and Merkel cell carcinoma $(n=1)$ (Figure 10). These zosteriform cutaneous metastases are often a sign of poor prognosis and may commonly be initially misdiagnosed as HZ [109,166-169] or 


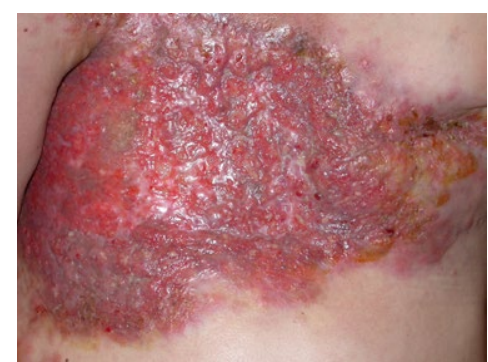

Figure 9. Cutaneous confluent metastases of breast carcinoma (Frontal aspect T4).

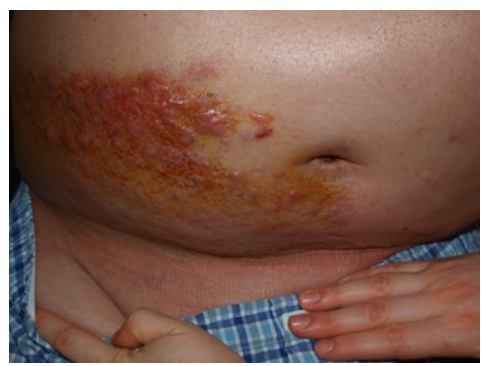

Figure 10. Cutaneous confluent metastases of Merkel cell carcinoma (Frontal aspect T11).

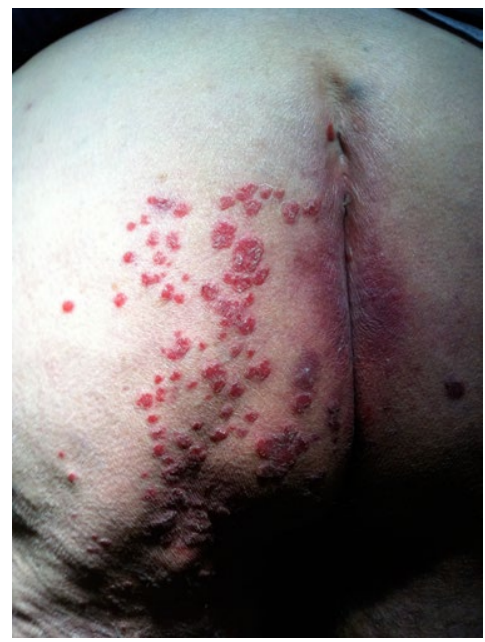

Figure 11. Zosteriform pityriasis lichenoides(Dorsal aspect, S3,S4)

as contact eczema $[133,157]$. In one study, 7 out of 15 cases of cutaneous zosteriform metastases were initially diagnosed as $\mathrm{HZ}$ and treated with antivirals [129]. Another study evidenced that 59\% of the zosteriform cutaneous metastasis cases had previously been diagnosed as $\mathrm{HZ}$ at the time of the initial examination and that many of them also had received antiviral therapy [143]. Other reports also relate erroneous treatment with antivirals for zosteriform cutaneous metastases [166-168]. The localization of the zosteriform cutaneous metastases is not indicative in the determination of the primary neoplasm. Indeed, zosteriform cutaneous metastases may be observed in the vicinity of the initial cancer, or be ipsilateral or contralateral, adjacent or at a distance [109]. In some rare cases, the initial tumor was discovered by the presence of zosterifom skin metastases [144,168]. Some benign skin tumors may present a zosteriform pattern, especially eccrine spiradenoma [170174] andtrichoepitheliomas [175].

Among the zosteriform infectious skin diseases, one should distinguish the chronic VZV infections that are rare but commonly present a zosteriform distribution and borrow the same pathway as classic HZ [176]. Incidental cases of zosteriform Leishmaniosis have been described [177-180].

Zosteriform inflammatory dermatoses are uncommon but present a great variety, including drug reactions to levofloxacin, trimethoprim and cephazolin [181,182]. Zosteriform lichen planus is the most frequently reported type of zosteriform lichen [183-190] and should be distinguished from linear lichen planus. A distinction with a lichenoid $\mathrm{HZ}$ should also be considered, especially as the treatment of the latter requires antiviral therapy and not dermocorticoids [191]. A punch biopsy with an immunohistochemical search for VZV readily distinguishes these entities [191]. Other types of lichen have been reported such as lichen aureus [192,193] and lichen sclerosus etatrophicus [194-196]. Exceptional cases are reported of zosteriform Darier's disease [197-200], pityriasis lichenoides (Figure 11), acneitis (Figure 12), morphea [201] and linear atrophoderma of Moulin [202].

Other dermatoses that may present a zosteriform pattern include the zosteriform nevus spilus [203], zosteriform naevus spilus with melanoma [159], progressive cribriform and zosteriform hyperpigmentation [204,205], zosteriform bleu nevi (Figure 13) and OTA nevus [145,206-210] (Figure 14), zosteriform melanocytic hyperpigmentation (Figure 15), Spitz nevi [211], unilateral nevoid telangiectasia [212-216] and notalgia paresthetica [217]. Connective tissue [218-224] and epidermal hamartomas [225,226], perforating

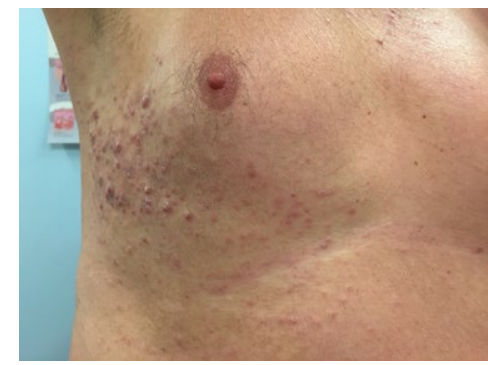

Figure 12. Zosteriform acneitis (Lateral aspect of $T 4,5$ )

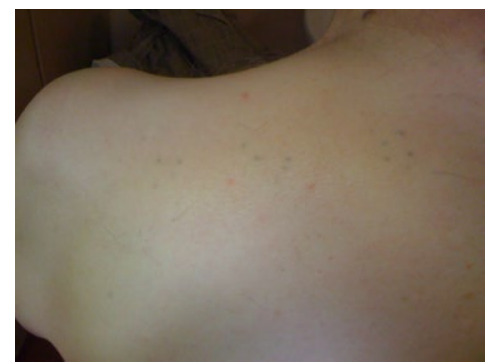

Figure 13. Several bleu naevi in a zosteriform distribution (Dorsal aspect C4).

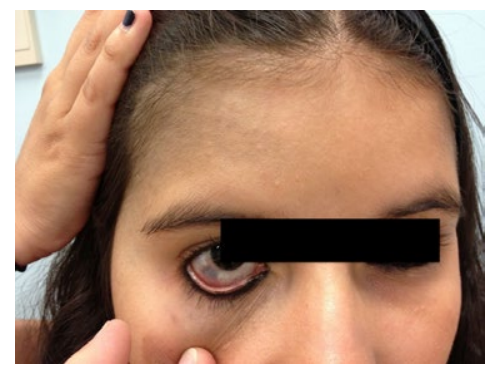

Figure 14. Zosteriform Ota naevus of the forehead with ocular pigmentation 


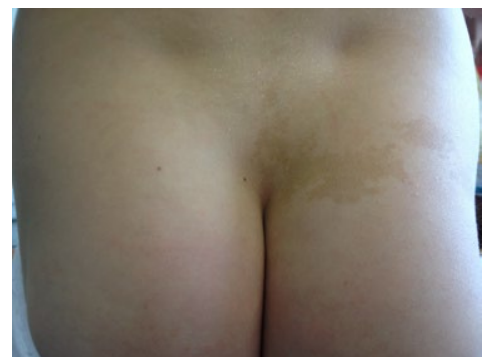

Figure 15. Zosteriform melanocytic hyperpigmentation (S1,S2).

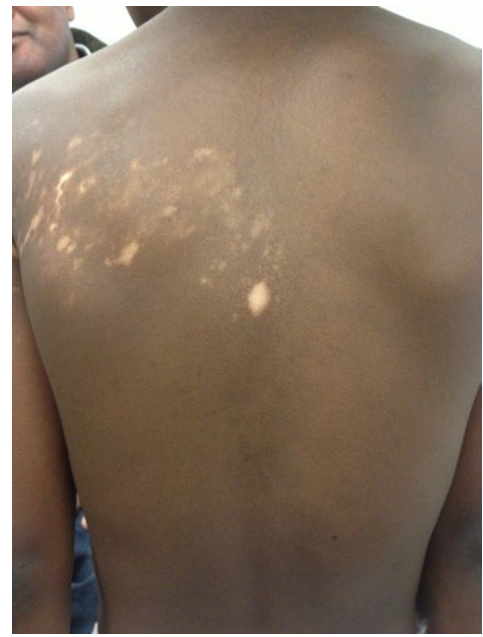

Figure 16. Zosteriform vitiligo along the dorsal aspect of the T2,T3 dermatomes.

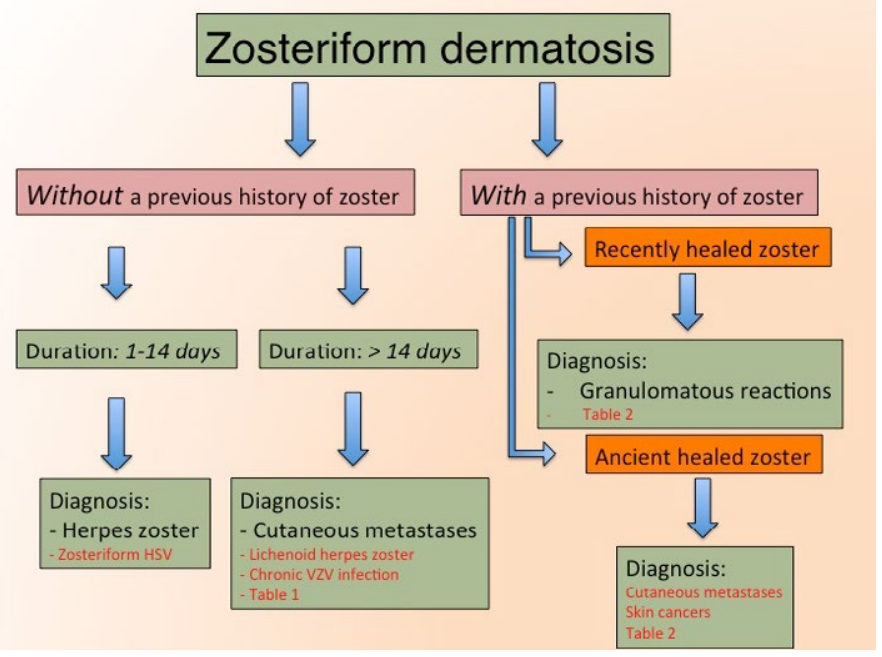

Figure 17. Algorithm for the differential diagnosis of a zosteriform dermatosis.

collagenosis [227], porokeratosis [228-231], arterio-venous malformations [232], epitheloid hemangioma [233], transient acantholytic dermatosis [234,235] and segmental vitiligo (Figure 16) may present with a zosteriform pattern [236-238].

\section{Diagnostic algorithm}

Figure 17 presents an algorithm helping the dermatologist in the differential diagnosis of an unilateral zosteriform eruption according to a history or not of previous $\mathrm{HZ}$ and taking into account the temporal evolution of the zosteriform dermatosis.

\section{Conclusion}

The first step in the differential diagnosis of a zosteriform dermatosis is to distinguish whether the eruption is restricted toa site of previous $\mathrm{HZ}$ or not. If not, recent zosteriform dermatoses include predominantly $\mathrm{HZ}$ and accessorily zosteriform HSV. More longstanding zosteriform dermatoses evoke primarily cutaneous metastases, particularly in the elder patient, followed by a series of inflammatory and other miscellaneous dermatoses. If the eruption develops on the site of previous andrecently healed HZ, the most probable diagnosis is a granulomatous reaction and at the site of an ancient healed site of $\mathrm{HZ}$, cutaneous metastases and skin cancer should primarily be considered.

\section{References}

1. Arvin AM (1996) Varicella-zoster virus: overview and clinical manifestations. Semin Dermatol 15: 4-7. [Crossref]

2. Nikkels AF, Piérard GE (2002) Oral antivirals revisited in the treatment of herpes zoster: what do they accomplish? Am J Clin Dermatol 3: 591-598. [Crossref]

3. Mueller NH, Gilden DH, Cohrs RJ, Mahalingam R, Nagel MA (2008) Varicella zoster virus infection: clinical features, molecular pathogenesis of disease, and latency. Neurol Clin 26: 675-697, viii. [Crossref]

4. Castronovo C, Nikkels AF (2012) Chronic herpes zoster duplex bilateralis. Acta Derm Venereol 92: 148-151. [Crossref]

5. Lee MW, McPhee RW, Stringer MD (2008) An evidence-based approach to human dermatomes. Clin Anat 21:363-373. [Crossref]

6. Forrest WM, Kaufman HE (1976) Zosteriform herpes simplex. Am J Ophthalmol 81 86-88. [Crossref]

7. Kalman CM, Laskin OL (1986) Herpes zoster and zosteriform herpes simplex virus infections in immunocompetent adults. Am J Med 81: 775-778. [Crossref]

8. Groisser D, Taylor S, Grossman ME (1990) Postsurgical zosteriform herpes simplex 2 in noncontiguous dermatomes. J Am Acad Dermatol 23: 928-930. [Crossref]

9. Ford RA (1993) Zosteriform eruption of herpes simplex virus after vertebral metastases. Cutis 52: 99-100. [Crossref]

10. Yamamoto S, Shimomura Y, Kinoshita S, Tano Y (1994) Differentiating zosteriform herpes simplex from ophthalmic zoster. Arch Ophthalmol 112: 1515-1516. [Crossref]

11. Rübben A, Baron JM, Grussendorf-Conen EI (1997) Routine detection of herpes simplex virus and varicella zoster virus by polymerase chain reaction reveals that initial herpes zoster is frequently misdiagnosed as herpes simplex. Br J Dermatol 137: 259261. [Crossref]

12. Summers BC, Margolis TP, Leib DA (2001) Herpes simplex virus type 1 corneal infection results in periocular disease by zosteriform spread. $J$ Virol 75: 5069-5075. [Crossref]

13. Goel N, Mao H, Rong Q, Docherty JJ, Zimmerman D, et al. (2002) The ability of an HSV strain to initiate zosteriform spread correlates with its neuroinvasive disease potential. Arch Virol 147: 763-773. [Crossref]

14. Kim KJ, Choi HJ, Suh HS, Lee MW, Choi JH, et al. (2003) Zosteriform herpetic folliculitis involving eccrine gland. J Dermatol 30: 929-930. [Crossref]

15. Koh MJ, Seah PP, Teo RY (2008) Zosteriform herpes simplex. Singapore Med J 49 e59-60. [Crossref]

16. Saito K, Hatano Y, Sakai T, Tatewaki S, Sako Y, et al. (2012) Primary ocular herpes simplex virus infection with zosteriform spreading, accompanied with meningism. $J$ Dermatol 39: 489-490. [Crossref]

17. Udayashankar C, Oudeacoumar P, Nath AK (2012) Recurrence of zosteriform lesion on the contralateral dermatome: A diagnostic dilemma. Indian Dermatol Online J 3: 76-77. [Crossref]

18. Aithal S, Kuruvila S, Ganguly S (2013) Zosteriform herpes simplex and herpes zoster: A clinical clue. Indian Dermatol Online J 4: 369. [Crossref]

19. Waroquier D, Vadoud J, Vereecken P, Vangeertruyden J, Laporte M (2004) Neurotropic metastasis of squamous cell carcinoma. Ann Dermatol Venereol 131: 187 189. [Crossref] 
20. Clément C, Lebreuilly I, Stephan A, De Raucourt S, Dutriaux C, et al. (2010) Intracranial extension of cutaneous facial squamous cell carcinoma: involvement of the neurotropic pathway. Ann Dermatol Venereol 137: 551-554. [Crossref]

21. Solares CA, Brown I, Boyle GM, Parsons PG, Panizza B (2009) Neural cell adhesion molecule expression: no correlation with perineural invasion in cutaneous squamous cell carcinoma of the head and neck. Head Neck 31: 802-806. [Crossref]

22. Solares CA, Boyle GM, Brown I, Parsons PG, Panizza B (2010) Reduced alphaBcrystallin staining in perineural invasion of head and neck cutaneous squamous cell carcinoma. Otolaryngol Head Neck Surg 142: S15-19. [Crossref]

23. Molina AR, Chatterton BD, Kalson NS, Fallowfield ME, Khandwala AR (2013) Multiple schwannomas of the upper limb related exclusively to the ulnar nerve in a patient with segmental schwannomatosis. J Plast Reconstr Aesthet Surg 66: e376-379. [Crossref]

24. Halder C, Sen S, Gangopadhyay A, Bala S (2013) Zosteriform palisaded encapsulated neuroma: an unusual presentation. Indian J Dermatol 58: 492. [Crossref]

25. Kouzak SS, Mendes MS, Costa IM (2013) Cutaneous mosaicisms: concepts, patterns and classifications. An Bras Dermatol 88: 507-517. [Crossref]

26. Lopes MR, Vilar AN, Pockstaller MP, Daher JG, Azulay DR (2014) Bilateral segmental neurofibromatosis. Int J Dermatol 53: 1136-1137. [Crossref]

27. Dragoni F, Bassi A, Conti R, Moretti S, Campolmi P (2013) Segmental neurofibromatosis type 1: a frequently underestimated disease. G Ital Dermatol Venereol 148: 706-707. [Crossref]

28. Wu J, Zhao J, Tian W. Segmental neurofibromatosis of the upper extremity: a case report. J Hand Surg Eur 32: 1538-1542. [Crossref]

29. Kroth J, Tischer J, Samtleben W, Weiss C, Ruzicka T, et al. (2011) Isotopic response, Köbner phenomenon and Renbök phenomenon following herpes zoster. J Dermatol 38: 1058-1061. [Crossref]

30. Wolf R, Brenner S, Ruocco V, Filioli FG (1995) Isotopic response. Int J Dermatol 34: 341-348. [Crossref]

31. Wolf R, Wolf D, Ruocco E, Brunetti G, Ruocco V (2011) Wolf's isotopic response. Clin Dermatol 29: 237-240. [Crossref]

32. Twersky JM, Nordlund JJ (2004) Cutaneous T-cell lymphoma sparing resolving dermatomal herpes zoster lesions: an unusual phenomenon and implications for pathophysiology. J Am Acad Dermatol 51: 123-126. [Crossref]

33. Nikkels AF, Sadzot-Delvaux C, Piérard GE (2004) Absence of intercellular adhesion molecule 1 expression in varicella zoster virus-infected keratinocytes during herpes zoster: another immune evasion strategy? Am J Dermatopathol 26: 27-32. [Crossref]

34. Gibney MD, Nahass GT, Leonardi CL (1996) Cutaneous reactions following herpes zoster infections: report of three cases and a review of the literature. $\mathrm{Br} J$ Dermatol 134: 504-509. [Crossref]

35. Serfling U, Penneys NS, Zhu WY, Sisto M, Leonardi C (1993) Varicella-zoster virus DNA in granulomatous skin lesions following herpes zoster. A study by the polymerase chain reaction. J Cutan Pathol 20: 28-33. [Crossref]

36. Fernández-Redondo V, Amrouni B, Varela E, Toribio J (2002) Granulomatous folliculitis at sites of herpes zoster scars: Wolf's isotopic response. $J$ Eur Acad Dermatol Venereol 16: 628-630. [Crossref]

37. Gesierich A, Krahl D, Weiss H, Bröcker EB, Rose C (2004) Granulomatous dermatitis following herpes zoster with detection of varicella zoster virus DNA. J Dtsch Dermatol Ges 2: 770-772. [Crossref]

38. Nikkels AF, Debrus S, Delvenne P, Sadzot-Delvaux C, Piette J, et al. (1994) Viral glycoproteins in herpesviridae granulomas. Am J Dermatopathol 16: 588-592. [Crossref]

39. Friedman SJ, Fox BJ, Albert HL (1986) Granuloma annulare arising in herpes zoster scars. Report of two cases and review of the literature. J Am Acad Dermatol 14: 764770. [Crossref]

40. Rodríguez-Pereira C, Suárez-Peñaranda JM, del Río E, Forteza-Vila J (1997) Cutaneous granulomatous vasculitis after herpes zoster infection showing polyarteritis nodosa-like features. Clin Exp Dermatol 22: 274-276. [Crossref]

41. Nikkels AF, Piérard GE (1998) Are granulomatous reactions in old zoster lesions due to an immune response to varicella zoster virus envelope glucoproteins? Clin Exp Dermatol 23: 237-238. [Crossref]

42. Requena L, Kutzner H, Escalonilla P, Ortiz S, Schaller J, et al. (1998) Cutaneous reactions at sites of herpes zoster scars: an expanded spectrum. Br J Dermatol 138: 161-168. [Crossref]

43. Schena D, Barba A, Chieregato C (2001) Granulomatous folliculitis as a manifestation of post-herpetic isotopic response. J Eur Acad Dermatol Venereol 15: 473-475. [Crossref]

44. Snow JL, el-Azhary RA, Gibson LE, Estes SA, Espy MJ, et al. (1997) Granulomatous vasculitis associated with herpes virus: a persistent, painful, postherpetic papular eruption. Mayo Clin Proc 72: 851-853. [Crossref]

45. Ezra N, Ahdout J, Haley JC, Chiu MW (2011) Granuloma annulare in a zoster scar of a patient with multiple myeloma. Cutis 87: 240-244. [Crossref]

46. Ruocco E, Baroni A, Cutrì FT, Filioli FG (2003) Granuloma annulare in a site of healed herpes zoster: Wolf's isotopic response. J Eur Acad Dermatol Venereol 17: 686-688. [Crossref]

47. Bisaccia E, Scarborough DA, Carr RD (1983) Cutaneous sarcoid granuloma formation in herpes zoster scars. Arch Dermatol 119: 788-789. [Crossref]

48. Fischer G, Jaworski R (1987) Granuloma formation in herpes zoster scars. J Am Acad Dermatol 16: 1261-1263. [Crossref]

49. Packer RH, Fields JP, King LE Jr (1984) Granuloma annulare in herpes zoster scars Cutis 34: 177-179. [Crossref]

50. Pujol RM, Matías-Guiu X, Planagumà M, de Moragas JM (1990) Chronic lymphocytic leukemia and cutaneous granulomas at sites of herpes zoster scars. Int J Dermatol 29 : 652-654. [Crossref]

51. Hayakawa K, Mizukawa Y, Shiohara T, Nagashima M (1992) Granuloma annulare arising after herpes zoster. Int J Dermatol 31: 745-746. [Crossref]

52. Krahl D, Hartschuh W, Tilgen W (1993) Granuloma annulare perforans in herpes zoster scars. J Am Acad Dermatol 29: 859-862. [Crossref]

53. Baalbaki SA, Malak JA, al-Khars MA, Natarajan S (1994) Granulomatous vasculitis in herpes zoster scars. Int J Dermatol 33: 268-269. [Crossref]

54. Wright AL, Cotton DW, Winfield DA, Messenger AG (1989) Granuloma formation in herpes zoster scars. Dermatologica 179: 45-46. [Crossref]

55. Barrazza V (1999) Post-herpes zoster scar sarcoidosis. Acta Derm Venereol 79: 495 [Crossref]

56. Cecchi R, Giomi A (1999) Scar sarcoidosis following herpes zoster. J Eur Acad Dermatol Venereol 12: 280-282. [Crossref]

57. Corazza M, Bacilieri S, Strumìa R (1999) Post-herpes zoster scar sarcoidosis. Acta Derm Venereol 79: 95. [Crossref]

58. Córdoba S, Fraga J, Bartolomé B, García-Díez A, Fernández-Herrera J (2000) Gian cell lichenoid dermatitis within herpes zoster scars in a bone marrow recipient. J Cutan Pathol 27: 255-257. [Crossref]

59. Ohata C, Shirabe H, Takagi K, Kawatsu T (2000) Granuloma annulare in herpes zoster scars. J Dermatol 27: 166-169. [Crossref]

60. Sanli HE, Koçyiğit P, Arica E, Kurtyüksel M, Heper AO, et al. (2006) Granuloma annulare on herpes zoster scars in a Hodgkin's disease patient following autologous peripheral stem cell transplantation. J Eur Acad Dermatol Venereol 20: 314-317. [Crossref]

61. Chang SE, Bae GY, Moon KC, Do SH, Lim YJ (2004) Subcutaneous granuloma annulare following herpes zoster. Int J Dermatol 43: 298-299. [Crossref]

62. Araki E, Kambe N, Takahashi K, Miyachi Y, Utani A (2007) Multiple dermatoma daughter lesions of postzoster granuloma. Br J Dermatol 156: 1369-1371. [Crossref]

63. Watanabe T, Yoshida Y, Yamamoto O (2009) Papules on the nape. Postherpetic granuloma annulare-like reaction (Wolf isotopic response). Arch Dermatol 145: 589594. [Crossref]

64. Watanabe D, Kuhara T, Ishida N, Tamada Y, Matsumoto Y (2009) Sarcoid tissue reaction on herpes zoster scars in a myelodysplastic syndrome patient: Wolf's isotopic response. J Eur Acad Dermatol Venereol 23: 475-477. [Crossref]

65. Ladoyanni E, Rajpar S, Rodriguo T, Snead D, Ahmed I (2010) An eruption after herpes zoster infection. Granulomatous reaction within atrophic VZV scars. Clin Exp Dermatol 35: 331-332. [Crossref]

66. De Somer L, Wouters C, Morren MA, De Vos R, Van Den Oord J, et al. (2010) Granulomatous skin lesions complicating Varicella infection in a patient with Rothmund-Thomson syndrome and immune deficiency: case report. Orphanet J Rare Dis 5: 37. [Crossref] 
67. Elgoweini M, Blessing K, Jackson R, Duthie F, Burden AD (2011) Coexistent granulomatous vasculitis and leukaemia cutis in a patient with resolving herpes zoster. Clin Exp Dermatol 36: 749-751. [Crossref]

68. Inaoka M, Kano Y, Horie C, Shiohara T (2011) Cutaneous granulomatous reaction after herpes zoster in drug-induced hypersensitivity syndrome. Am J Dermatopathol 33: 872-874. [Crossref]

69. Niedermeier A, Flaig MJ, Rupec RA, Ruzicka T (2011) Persistent granulomatous plaque type zoster in a patient with HIV infection. Int $J$ Dermatol 50: 368-370. [Crossref]

70. Nakano M, Takeshita H, Hayashida S, Takahara M, Shimokama T, et al. (2012) Granulomatous reaction at the site of healed herpes zoster in a patient with adult T-cell leukemia/lymphoma. J Dermatol 39: 407-409. [Crossref]

71. Kapoor R, Piris A, Saavedra AP, Duncan LM, Nazarian RM (2013) Wolf isotopic response manifesting as postherpetic granuloma annulare: a case series. Arch Pathol Lab Med 137: 255-258. [Crossref]

72. Singal A, Vij A, Pandhi D (2014) Post herpes-zoster scar sarcoidosis with pulmonary involvement. Indian Dermatol Online J 5: 77-79. [Crossref]

73. Wright NA, Torres-Cabala CA, Curry JL, Cutlan JE, Hymes SR (2014) Post-varicellazoster virus granulomatous dermatitis: a report of 2 cases. Cutis 93: 50-54. [Crossref]

74. Paydaș S, Sahin B, Yavuz S, Tuncer I, Gönlüșen G (2000) Lymphomatous skin infiltration at the site of previous varicella zoster virus infection in a patient with $\mathrm{T}$ cell lymphoma. Leuk Lymphoma 37: 229-232. [Crossref]

75. Talpur R, Duvic M (2003) Atypical lymphoid infiltration occurring at the site of a healed varicella zoster infection. Clin Lymphoma 3: 253-256. [Crossref]

76. Cerroni L, Zenahlik P, Kerl H (1995) Specific cutaneous infiltrates of B-cell chronic lymphocytic leukemia arising at the site of herpes zoster and herpes simplex scars. Cancer 76: 26-31. [Crossref]

77. Hudson CP, Hanno R, Callen JP (1984) Cutaneous angiosarcoma in a site of healed herpes zoster. Int J Dermatol 23: 404-407. [Crossref]

78. Kast DR, Sammons D, Nixon RM, Geiss DF (2012) Cutaneous angiosarcoma masquerading as herpes zoster. Cutis 90: 42-45. [Crossref]

79. Sanli H, Anadolu R, Arat M, Ekmekci P, Birol A, et al. (2003) Dermatomal lichenoid graft-versus-host disease within herpes zoster scars. Int J Dermatol 42: 562-564. [Crossref]

80. Baselga E, Drolet BA, Segura AD, Leonardi CL, Esterly NB (1996) Dermatomal lichenoid chronic graft-vs-host disease following varicella-zoster infection despite absence of viral genome. J Cutan Pathol 23: 576-581. [Crossref]

81. Freemer CS, Farmer ER, Corio RL, Altomonte VL, Wagner JE, et al. (1994) Lichenoid chronic graft-vs-host disease occurring in a dermatomal distribution. Arch Dermatol 130: 70-72. [Crossref]

82. Forschner A, Metzler G, Rassner G, Fierlbeck G (2005) Morphea with features of lichen sclerosus et atrophicus at the site of a herpes zoster scar: another case of an isotopic response. Int J Dermatol 44: 524-525. [Crossref]

83. Noh TW, Park SH, Kang YS, Lee UH, Park HS, et al. (2011) Morphea developing at the site of healed herpes zoster. Ann Dermatol 23: 242-245. [Crossref]

84. Lee HJ, Ahn WK, Chae KS, Ha SJ, Kim JW (1999) Localized chronic urticaria at the site of healed herpes zoster. Acta Derm Venereol 79: 168. [Crossref]

85. Huang CW, Tu ME, Wu YH, Lin YC (2007) Isotopic response of fungal granuloma following facial herpes zoster infections - report of three cases. Int J Dermatol 46: 1141-1145. [Crossref]

86. Ferahbas A, Alpay K, Agaoglu C (1997) Dermatophytosis in healing herpes zoster lesions. Cutis 60: 51-52. [Crossref]

87. Nico MM, Bergonse FN, Godoy AM (2001) Molluscum contagiosum in herpes zoster scars. Int J Dermatol 40: 521-524. [Crossref]

88. Manikhas MG, Egorova MA, Orlova EV (1986) Keloid scars as a sequel of herpes zoster. Vestn Dermatol Venerol: 54-55. [Crossref]

89. Koley S, Saoji V, Salodkar A (2009) Unusual formation of keloids after each episode of recurrent herpes zoster in an HIV positive patient. Indian J Sex Transm Dis 30: 109-111. [Crossref]

90. Bellavista S, D’Antuono A, Gaspari V, Banzola N, Patrizi A (2012) Acne keloidalis nuchae on herpes zoster scar in an HIV patient: isotopic response or not? G Ital Dermatol Venereol 147: 223-226. [Crossref]
91. Sardana K, Relhan V, Sehgal VN, Garg VK, Kochhar AM (2007) Occurrence of acne comedones over healed linear scar of herpes zoster: a neurogenic perception. $J$ Eur Acad Dermatol Venereol 21: 431-432. [Crossref]

92. Puskás M, Schneider I, Dull G, Zombai E (1995) Post-Herpes Zoster calcinosis. Ann Dermatol Venereol 122: 436-438. [Crossref]

93. Takayama N, Takayama M, Takita J (2001) Herpes simplex mimicking herpes zoster in a child immunized with varicella vaccine. Pediatr Infect Dis J 20: 226-228. [Crossref]

94. Netherton EW (1948) Leukemic infiltration in scars of herpes zoster generalisatus. Arch Derm Syphilol 57: 782. [Crossref]

95. Buecker JW, Ratz JL (1984) Cutaneous metastatic squamous-cell carcinoma in zosteriform distribution. J Dermatol Surg Oncol 10: 718-720. [Crossref]

96. Aloi FG, Appino A, Puiatti P (1990) Lymphoplasmocytoid lymphoma arising in herpes zoster scars. J Am Acad Dermatol 22: 130-131. [Crossref]

97. Marzano AV, Berti E, Alessi E (1999) Primary cutaneous B-cell lymphoma with a dermatomal distribution. J Am Acad Dermatol 41: 884-886. [Crossref]

98. Ricci RM, Latham PL, Soong V, Mullins D (1995) Zosteriform cutaneous T-cell lymphoma. J Am Acad Dermatol 32: 127-128. [Crossref]

99. Shafqat A, Viehman GE, Myers SA (1997) Cutaneous squamous cell carcinoma with zosteriform metastasis in a transplant recipient. J Am Acad Dermatol 37: 1008-1009. [Crossref]

100. Cuq-Viguier L, Viraben R (1998) Zosteriform cutaneous metastases from squamous cell carcinoma of the stump of an amputated arm. Clin Exp Dermatol 23: 116-118. [Crossref]

101. Fearfield LA, Nelson M, Francis N, Bunker CB (2000) Cutaneous squamous cell carcinoma with zosteriform metastases in a human immunodeficiency virus-infected patient. Br J Dermatol 142: 573-574. [Crossref]

102. Eisman S, O’Toole EA, Collis C, Rustin MH (2001) Zosteriform Kaposi's sarcoma Clin Exp Dermatol 26: 402-404. [Crossref]

103. Kato N, Aoyagi S, Sugawara H, Mayuzumi M (2001) Zosteriform and epidermotropic metastatic primary cutaneous squamous cell carcinoma. Am J Dermatopathol 23: 216220. [Crossref]

104. Bauzá A, Redondo P, Idoate MA (2002) Cutaneous zosteriform squamous cell carcinoma metastasis arising in an immunocompetent patient. Clin Exp Dermatol 27 199-201. [Crossref]

105. Kazakov DV, Burg G, Dummer R, Kempf W (2002) Cutaneous lymphomas and pseudolymphomas: newly described entities. Recent Results Cancer Res 160: 283293. [Crossref]

106. Watabe H, Kawakami T, Soma Y, Baba T, Mizoguchi M (2002) Primary cutaneous T-cell-rich B-cell lymphoma in a zosteriform distribution associated with EpsteinBarr virus infection. J Dermatol 29: 748-753. [Crossref]

107. Cohen JL, Barankin B, Zloty DM, Mikhail GR (2004) Metastatic zosteriform squamous cell carcinoma in an immunocompetent patient. J Cutan Med Surg 8: 438441. [Crossref]

108. Minakawa S, Nakajima K, Aizu T, Kaimori M, Nomura K (2008) A case of zosteriform metastatic skin cancer. Clin Exp Dermatol 33: 808-810. [Crossref]

109. Kishan KH, Rao G (2013) A rare case of zosteriform cutaneous metastases from squamous cell carcinoma of hard palate. Ann Med Health Sci Res 3: 127-130. [Crossref]

110. New WN (1949) Leiomyoma cutis (zosteriform). Arch Derm Syphilol 60: 461 [Crossref]

111. Bluefarb SM, Wallk S, Gecht M (1957) Carcinoma of the prostate with zosteriform cutaneous lesions. AMA Arch Derm 76: 402-407. [Crossref]

112. Hodge SJ, Mackel S, Owen LG (1979) Zosteriform inflammatory metastatic carcinoma. Int J Dermatol 18: 142-145. [Crossref]

113. Lindscheid KR, Zabel M (1990) Zosteriform leiomyomatosis--successful treatment by iontophoresis with tap water. Z Hautkr 65: 923-926. [Crossref]

114. Manteaux A, Cohen PR, Rapini RP (1992) Zosteriform and epidermotropic metastasis Report of two cases. J Dermatol Surg Oncol 18: 97-100. [Crossref]

115. Ando K, Goto Y, Kato K, Murase T, Matsumoto Y, et al. (1994) Zosteriform inflammatory metastatic carcinoma from transitional cell carcinoma of the renal pelvis. J Am Acad Dermatol 31: 284-286. [Crossref] 
116. Itin PH, Lautenschlager S, Buechner SA (1995) Zosteriform metastases in melanoma. $J$ Am Acad Dermatol 32: 854-857. [Crossref]

117. Heckmann M, Volkenandt M, Lengyel ER, Schirren CG, Gizycki-Nienhaus BV (1996) Cytological diagnosis of zosteriform skin metastases in undiagnosed breast carcinoma. Br J Dermatol 135: 502-503. [Crossref]

118. Wakelin SH, Young E, Kelly S, Turner M (1997) Transient leukaemia cutis in chronic lymphocytic leukaemia. Clin Exp Dermatol 22: 37-40. [Crossref]

119. Cecchi R, Brunetti L, Bartoli L, Pavesi M, Giomi A (1998) Zosteriform skin metastases from breast carcinoma in association with herpes zoster. Int $J$ Dermatol 37: 476-477. [Crossref]

120. Matarasso SL, Rosen T (1988) Zosteriform metastasis: case presentation and review of the literature. J Dermatol Surg Oncol 14: 774-778. [Crossref]

121. North S, Mackey JR, Jensen J (1998) Recurrent malignant melanoma presenting with zosteriform metastases. Cutis 62: 143-146. [Crossref]

122. Smith CG, Glaser DA, Leonardi C (1998) Zosteriform multiple leiomyomas. J Am Acad Dermatol 38: 272-273. [Crossref]

123. Maeda S, Hara H, Morishima T (1999) Zosteriform cutaneous metastases arising from adenocarcinoma of the colon: diagnostic smear cytology from cutaneous lesions. Acta Derm Venereol 79: 90-91. [Crossref]

124. Agarwalla A, Thakur A, Jacob M, Joshi A, Garg VK, et al. (2000) Zosteriform and disseminated lesions in cutaneous leiomyoma. Acta Derm Venereol 80: 446. [Crossref]

125. Ahmed I, Holley KJ, Charles-Holmes R (2000) Zosteriform metastasis of colonic carcinoma. Br J Dermatol 142: 182-183. [Crossref]

126. Au WY, Chan AC, Kwong YL (2000) Zosteriform relapse of B-cell lymphoma. Br J Dermatol 142: 180-182. [Crossref]

127. Bianchi L, Orlandi A, Carboni I, Costanzo A, Chimenti S (2000) Zosteriform metastasis of occult bronchogenic carcinoma. Acta Derm Venereol 80: 391-392. [Crossref]

128. Cuerda Galindo E, Sánchez de Paz F, Mansilla Pérez I, Poza Madalena O, Casellas Bravo M (2000) Malignant melanoma with zosteriform metastases. Cutis 65: 312-314. [Crossref]

129. Kikuchi Y, Matsuyama A, Nomura K (2001) Zosteriform metastatic skin cancer: report of three cases and review of the literature. Dermatology 202: 336-338. [Crossref]

130. Sahoo B, Radotra BD, Kaur I, Kumar B (2001) Zosteriform pilar leiomyoma. $J$ Dermatol 28: 759-761. [Crossref]

131. Damin DC, Lazzaron AR, Tarta C, Cartel A, Rosito MA (2003) Massive zosteriform cutaneous metastasis from rectal carcinoma. Tech Coloproctol 7: 105-107. [Crossref]

132. Evans AV, Child FJ, Russell-Jones R (2003) Zosteriform metastasis from melanoma. $B M J$ 326: 1025-1026. [Crossref]

133. Lin CY, Lee CT, Huang JS, Chang LC (2003) Transitional cell carcinoma metastasis to arm skin from the renal pelvis. Chang Gung Med J 26: 525-529. [Crossref]

134. Zalaudek I, Leinweber B, Richtig E, Smolle J, Hofmann-Wellenhof R (2003) Cutaneous zosteriform melanoma metastases arising after herpes zoster infection: a case report and review of the literature. Melanoma Res 13: 635-639. [Crossref]

135. García-Morales I, Herrera-Saval A, Ríos JJ, Camacho F (2004) Zosteriform cutaneous metastases from Hodgkin's lymphoma in a patient with scrofuloderma and nodal tuberculosis. Br J Dermatol 151: 722-724. [Crossref]

136. Martínez Fernández M, Sambucety PS, Prieto MA (2004) Zosteriform metastatic melanoma. Int J Dermatol 43: 666-667. [Crossref]

137. Bach AG, Marsch WC, Richter C, Lübbe D, Helmbold P (2005) Long-term locallyrecurrent melanoma. Hautarzt 56: 949-954. [Crossref]

138. Bassioukas K, Nakuci M, Dimou S, Kanellopoulou M, Alexis I (2005) Zosteriform cutaneous metastases from breast adenocarcinoma. J Eur Acad Dermatol Venereol 19: 593-596. [Crossref]

139. Woodruff CA, Amrikachi M, Hsu S (2005) Zosteriform metastatic transitional cell carcinoma. Int J Dermatol 44: 1028-1030. [Crossref]

140. Kamisawa T, Takahashi M, Nakajima H, Egawa N (2006) Gastrointestinal: Zosteriform metastases to the skin. J Gastroenterol Hepatol 21: 620. [Crossref]

141. Torchia D, Palleschi GM, Terranova M, Antiga E, Melani L, et al. (2006) Ulcerative carcinoma of the breast with zosteriform skin metastases. Breast J 12: 385. [Crossref]
142. Chaves AJ, Fernández-Recio JM, de Argila D, Rodríguez-Nevado I, Catalina M (2007) Zosteriform cutaneous leiomyoma. Satisfactory treatment with oral doxazosin. Actas Dermosifiliogr 98: 494-496. [Crossref]

143. Niiyama S, Satoh K, Kaneko S, Aiba S, Takahashi M, et al. (2007) Zosteriform skin involvement of nodal T-cell lymphoma: a review of the published work of cutaneous malignancies mimicking herpes zoster. J Dermatol 34: 68-73. [Crossref]

144. Rasi A, Tajziehchi L, Shaianfar N (2007) Metastatic carcinoma of the ovary presenting as zosteriform lesions. Arch Iran Med 10: 250-252. [Crossref]

145. Claeys A, Pouaha J, Christian B, Froment N, Truchetet F (2008) Zosteriform cutaneous localizations of B-cell chronic lymphocytic leukaemia. Eur J Dermatol 18: 101-102. [Crossref]

146. Monteagudo Sánchez B, Cabanillas González M, Pérez Fernández A, de la Cámara Gómez J, Campo Cerecedo F. Zosteriform cutaneous metastases of malignant pleural mesothelioma. Rev Clin Esp 209: 262-263. [Crossref]

147. Savoia P, Fava P, Deboli T, Quaglino P, Bernengo MG (2009) Zosteriform cutaneous metastases: a literature meta-analysis and a clinical report of three melanoma cases. Dermatol Surg 35: 1355-1363. [Crossref]

148. Werchau S, Hartschuh W, Hartmann M (2009) Zosteriform metastasis of endometrial cancer. Eur J Dermatol 19: 401-402. [Crossref]

149. Al Zouman A, Al Harthi F (2010) Male breast carcinoma with zosteriform metastasis. Breast J 16: 88-89. [Crossref]

150. Augustin G, Kekez T, Bogdanic B (2010) Abdominal papular zosteriform cutaneous metastases from endometrial adenocarcinoma. Int J Gynaecol Obstet 110: 74. [Crossref]

151. Lakshmi C, Pillai SB, Sharma C, Srinivas CR (2010) Carcinoma en cuirasse of the breast with zosteriform metastasis. Indian J Dermatol Venereol Leprol 76: 215. [Crossref]

152. Rao R, Balachandran C, Rao L (2010) Zosteriform cutaneous metastases: a case report and brief review of literature. Indian J Dermatol Venereol Leprol 76: 447. [Crossref]

153. Ali MM, Al-Daraji WI (2011) Painful, erythematous, zosteriform nodules on the back, arms and abdomen. Clin Exp Dermatol 36: 820-821. [Crossref]

154. Antunes J, Pacheco D, Travassos R, Filipe P (2011) Zosteriform B-cell chronic lymphocytic leukemia infiltration. Dermatol Online J 17: 9. [Crossref]

155. Chandanwale SS, Gore CR, Buch AC, Misal SS (2011) Zosteriform cutaneous metastasis: a primary manifestation of carcinoma breast, rare case report. Indian J Pathol Microbiol 54: 863-864. [Crossref]

156. Dincer D, Tunca M, Akar A, Kurt B (2011) Zosteriform cutaneous metastasis of renal cell carcinoma. Indian J Dermatol Venereol Leprol 77: 340-342. [Crossref]

157. Eichinger J, George B, Myhand R (2011) Cutaneous metastatic rectal carcinoma masquerading as herpes zoster. South Med J 104: 233-235. [Crossref]

158. Virmani NC, Sharma YK, Panicker NK, Dash KN, Patvekar MA, et al. (2011) Zosteriform skin metastases: clue to an undiagnosed breast cancer. Indian J Dermatol 56: 726-727. [Crossref]

159. Cecchi R, Fancelli L, Troiano M (2012) Melanoma arising in giant zosteriform nevus spilus. Indian J Dermatol Venereol Leprol 78: 643-645. [Crossref]

160. González-Hernández S, Pérez-Robayna N, Rodríguez-García C, Sánchez-González R (2012) Cutaneous metastases with zosteriform pattern from a breast carcinoma. Med Clin (Barc) 138: 460. [Crossref]

161. Hapgood G, Mooney E, Dinh HV, Gin D, McLean C, et al. (2012) Leukaemia cutis in chronic lymphocytic leukaemia following varicella zoster virus reactivation. Intern Med J 42: 1355-1358. [Crossref]

162. Li WH, Tu CY, Hsieh TC, Wu PY (2012) Zosteriform skin metastasis of lung cancer. Chest 142: 1652-1654. [Crossref]

163. Trojjet S, Hammami H, Zaraa I, Bouzguarrou A, Joens M, et al. (2012) Chronic lymphocytic leukemia revealed by a branulomatous zosteriform eruption. Skinmed 10: 50-52. [Crossref]

164. Zucchi A, Aimi F, Cardis A, Santini M, Tognetti E, et al. (2012) Unusual form of cutaneous infiltration by cancer. Acta Biomed 83: 51-52. [Crossref]

165. Arfan-ul-Bari (2013) Zosteriform cutaneous leiomyoma: a rare cutaneous neoplasm. $J$ Coll Physicians Surg Pak 23: 586-587. [Crossref]

166. Lookingbill DP, Spangler N, Sexton FM (1990) Skin involvement as the presenting 
sign of internal carcinoma. A retrospective study of 7316 cancer patients. $J$ Am Acad Dermatol 22: 19-26. [Crossref]

167. Williams LR, Levine LJ, Kauh YC (1991) Cutaneous malignancies mimicking herpes zoster. Int J Dermatol 30: 432-434. [Crossref]

168. LeSueur BW, Abraham RJ, DiCaudo DJ, O'Connor WJ (2004) Zosteriform skin metastases. Int J Dermatol 43: 126-128. [Crossref]

169. Hussein MR (2010) Skin metastasis: a pathologist's perspective. J Cutan Pathol 37: e1-20. [Crossref]

170. Shelley WB, Wood MG (1980) A zosteriform network of spiradenomas. $J$ Am Acad Dermatol 2: 59-61. [Crossref]

171. Criton S, Aravindan KP (1996) Zosteriform network of spiradenoma. Indian $J$ Dermatol Venereol Leprol 62: 185-186. [Crossref]

172. Gupta S, Jain VK, Singh U, Gupta S (2000) Multiple eccrine spiradenomas in zosteriform distribution in a child. Pediatr Dermatol 17: 384-386. [Crossref]

173. Altinyazar HC, Kargi E, Ozen O, Koca R, Babucçu O (2003) Multiple eccrine spiradenoma in zosteriform distribution. Plast Reconstr Surg 112: 927-928. [Crossref]

174. Alfonso-Trujillo I, Arteaga-Hernández E, Pérez-Suárez JC (2009) Eccrine spiradenoma in a zosteriform distribution: presentation of a case. Actas Dermosifiliogr 100: 619-620. [Crossref]

175. Geffner RE, Goslen JB, Santa Cruz DJ (1986) Linear and dermatomal trichoepitheliomas. J Am Acad Dermatol 14: 927-930. [Crossref]

176. Wauters O, Lebas E, Nikkels AF (2012) Chronic mucocutaneous herpes simplex virus and varicella zoster virus infections. J Am Acad Dermatol 66: e217-227. [Crossref]

177. Omidian M, Mapar MA (2006) Chronic zosteriform cutaneous leishmaniasis. Indian $J$ Dermatol Venereol Leprol 72: 41-42. [Crossref]

178. Ceyhan AM, Yildirim M, Basak PY, Akkaya VB, Erturan I (2008) A case of erysipeloid cutaneous leishmaniasis: atypical and unusual clinical variant. Am J Trop Med Hyg 78: 406-408. [Crossref]

179. Bari AU, Rahman SB (2008) Many faces of cutaneous leishmaniasis. Indian $J$ Dermatol Venereol Leprol 74: 23-27. [Crossref]

180. Bongiorno MR, Pistone G, Aricò M (2009) Unusual clinical variants of cutaneous leishmaniasis in Sicily. Int J Dermatol 48: 286-289. [Crossref]

181. Vetrichevvel TP, Sudha R, Shobana S, Anandan S (2012) Zosteriform fixed drug eruption to levofloxacin. Indian J Dermatol 57: 327-328. [Crossref]

182. Sultan SJ, Sameem F (2012) Two contrasting post-zoster dermatomal phenomena Skinmed 10: 312-314. [Crossref]

183. Braun RP, Barua D, Masouyé I (1998) Zosteriform lichen planus after herpes zoster. Dermatology 197: 87-88. [Crossref]

184. Arfan-ul-Bari, Rahman SB (2003) Zosteriform Lichen planus. J Coll Physicians Surg Pak 13: 104-105. [Crossref]

185. Miljkoviäł J, Belic M, GodiÄ $\ddagger$ A, Klemenc P, Marin J (2006) Zosteriform lichen planus-like eruption. Acta Dermatovenerol Alp Pannonica Adriat 15: 94-97. [Crossref]

186. Perry D, Fazel N (2006) Zosteriform lichen planus. Dermatol Online J 12: 3. [Crossref]

187. Ber Rahman S, Ul Bari A, Mumtaz N (2007) Unilateral Blaschkoid lichen planus involving the entire half of the body, a unique presentation. Dermatol Online $J 13$ : 36. [Crossref]

188. Ganguly S, Jaykar KC (2012) Twenty nail dystrophy in association with zosteriform lichen planus. Indian J Dermatol 57: 329. [Crossref]

189. Mizukawa Y, Horie C, Yamazaki Y, Shiohara T (2012) Detection of varicella-zoster virus antigens in lesional skin of zosteriform lichen planus but not in that of linear lichen planus. Dermatology 225: 22-26. [Crossref]

190. Turan E, Akay A, Yesilova Y, Türkçü G (2012) A case of zosteriform lichen planus developing after extracorporeal shockwave lithotripsy. Dermatol Online $J$ 18: 9. [Crossref]

191. Nikkels AF, Sadzot-Delvaux C, Rentier B, Piérard-Franchimont C, Piérard GE (1998) Low-productive alpha-herpesviridae infection in chronic lichenoid dermatoses. Dermatology 196: 442-446. [Crossref]

192. Crippa D, Nicoletti A, Puccini S, Sala G, Beneggi M, et al. (1989) Lichen aureus with zonal dissemination. Apropos of a case. G Ital Dermatol Venereol 124: 163-165. [Crossref]
193. Dippel E, Schröder K, Goerdt S (1998) Zosteriform lichen aureus. Hautarzt 49: 135138. [Crossref]

194. Möhrenschlager M, Engst R, Hein R, Ring J (2008) Primary manifestation of a zosteriform lichen planus: isotopic response following herpes zoster sine herpete? $\mathrm{Br}$ J Dermatol 158: 1145-1146. [Crossref]

195. Cabanillas González M, Monteagudo B, de las Heras C, Cacharrón JM (2009) Blaschkoid, zosteriform linear lichen sclerosus et atrophicus. Actas Dermosifiliogr 100: 155-157. [Crossref]

196. Chen JF, Chiang CP, Chen YF (2010) Bilateral zosteriform extragenital lichen sclerosus et atrophicus: a new clinical presentation. J Dermatol 37: 480-483. [Crossref]

197. Stojanović S, Poljacki M, Jovanović M, Tasić S (2001) Darier's disease--a familial case report. Med Pregl 54: 375-379. [Crossref]

198. Meziane M, Chraibi R, Kihel N, Hassam B, Senouci K (2008) Linear Darier disease Dermatology Online J 14: 11. [Crossref]

199. Goldberg EI, Lefkovits AM, Sapadin AN (2001) Zosteriform Darier's disease versus acantholytic dyskeratotic epidermal nevus. Mt Sinai J Med 68: 339-341. [Crossref]

200. Gupta LK, Garg A, Khare AK, Mittal A (2013) A case of zosteriform Darier's disease with seasonal recurrence. Indian Dermatol Online J 4: 219-221. [Crossref]

201. Ruiz-Villaverde R, Sánchez-Cano D (2013) Zosteriform morphea in an immunocompetent patient. Indian J Dermatol 58: 411. [Crossref]

202. Patsatsi A, Kyriakou A, Chaidemenos G, Sotiriadis D (2013) Linear atrophoderma of Moulin: a case report and review of the literature. Dermatol Pract Concept 3: 7-11. [Crossref]

203. Hu N, Zhong J, Yang B, Wang L, Li L (2013) A case of zosteriform nevus spilus with halo nevus. Int J Dermatol 52: 386-388. [Crossref]

204. Goyal T (2013) Progressive cribriform and zosteriform hyperpigmentation: Where are we at present? Indian Dermatol Online J 4: 264-266. [Crossref]

205. Gutte RM (2014) Progressive cribriform and zosteriform hyperpigmentation. Indian Dermatol Online J 5: 38-40. [Crossref]

206. Sharma PK, Gautam RK, Parsad D, Jain RK, Kar HK (1996) Progressive reticulate zosteriform hyperpigmentation. Indian J Dermatol Venereol Leprol 62: 262-263. [Crossref]

207. Schepis C, Alberti A, Siragusa M, Romano C (1999) Progressive cribriform and zosteriform hyperpigmentation: the late-onset feature of linear and whorled nevoid hypermelanosis associated with congenital neurological, skeletal and cutaneous anomalies. Dermatology 199: 72-73. [Crossref]

208. Sehgal VN, Srivastava G (2007) Vitiligo: compendium of clinico-epidemiological features. Indian J Dermatol Venereol Leprol 73: 149-156. [Crossref]

209. Patrizi A, Di Lernia V, Varotti C (1989) Reticulate hyperpigmentation distributed in a zosteriform fashion. Br J Dermatol 121: 280. [Crossref]

210. Di Lernia V (2007) Linear and whorled hypermelanosis. Pediatr Dermatol 24: 205210. [Crossref]

211. Glasgow MA, Lain EL, Kincannon JM (2005) Agminated Spitz nevi: report of a child with a unique dermatomal distribution. Pediatr Dermatol 22: 546-549. [Crossref]

212. Wenson SF, Jan F, Sepehr A (2011) Unilateral nevoid telangiectasia syndrome: a case report and review of the literature. Dermatol Online J 17: 2. [Crossref]

213. Senel E, Gulec AT (2008) Congenital unilateral naevoid telangiectasia with a wide dermatomal distribution. Clin Exp Dermatol 33: 663-664. [Crossref]

214. Karakaay M, Durdu M, Sanmezoaylu S, Akman A, Gamardaa D (2004) Unilatera nevoid telangiectasia. J Dermatol 31: 109-112. [Crossref]

215. Wilkin JK, Smith JG Jr, Cullison DA, Peters GE, Rodriquez-Rigau LJ, et al. (1983) Unilateral dermatomal superficial telangiectasia. Nine new cases and a review of unilateral dermatomal superficial telangiectasia. $J$ Am Acad Dermatol 8: 468-477. [Crossref]

216. Wilkin JK (1980) Unilateral dermatomal cavernous hemangiomatosis. Dermatologica 161: 347-354. [Crossref]

217. Ellis C (2013) Notalgia paresthetica: the unreachable itch. Dermatol Pract Concept 3: 3-6. [Crossref]

218. Kozminsky ME, Bronson DM, Barsky S (1985) Zosteriform connective-tissue nevus. Cutis 36: 77-78. [Crossref] 
219. Yeh SW, Magalhaes AM, Vasconcellos MR, Michalany NS, Tomimori Yamashita J (2003) Zosteriform connective tissue nevus: a case report. Int J Dermatol 42: 720722. [Crossref]

220. Amjadi M, Khorrami-Arani N, Mashman G, Allen PW (2007) Zosteriform connective tissue nevus: a case report. Am J Dermatopathol 29: 303-305. [Crossref]

221. Brazzelli V, Muzio F, Barbagallo T, Fornara L, Donadini F, et al. (2007) Zosteriform connective tissue nevus in a pediatric patient. Pediatr Dermatol 24: 557-558. [Crossref]

222. De D, Kanwar AJ, Dogra S (2007) Collagen naevus in a zosteriform distribution. Clin Exp Dermatol 32: 324-325. [Crossref]

223. Choi YJ, Lee SJ, Choi CW, Kim WS, Lee GY (2011) Multiple unilateral zosteriform connective tissue nevi on the trunk. Ann Dermatol 23: S243-246. [Crossref]

224. Castellanos-González M, Petiti-Martín G, Postigo C, Rodriguez-Peralto JL (2012) Zosteriform connective tissue nevus: a new case report. Actas Dermosifiliogr 103 640-642. [Crossref]

225. Elston DM (1999) Zosteriform distribution of acantholytic dyskeratotic epiderma nevus? J Am Acad Dermatol 40: 647. [Crossref]

226. Song BH, Park S, Park EJ, Kwon IH, Kim KH, et al. (2012) Mucinous nevus with fat: an unusual case report and literature review. Am J Dermatopathol 34: e146-148. [Crossref]

227. Nakanishi G, Tsunemitsu R, Akagi O (1999) Reactive perforating collagenosis occurring in a zosteriform distribution. Br J Dermatol 141: 367-369. [Crossref]

228. Agrawal SK, Gandhi V, Madan V, Bhattacharya SN (2003) Topical tretinoin in Indian male with zosteriform porokeratosis. Int J Dermatol 42: 919-920. [Crossref]
229. Dervis E, Demirkesen C (2006) Generalized linear porokeratosis. Int J Dermatol 45: 1077-1079. [Crossref]

230. Malhotra SK, Puri KJ, Goyal T, Chahal KS (2007) Linear porokeratosis. Dermatol Online J 13: 15. [Crossref]

231. Hong JB, Hsiao CH, Chu CY (2009) Systematized linear porokeratosis: a rare varian of diffuse porokeratosis with good response to systemic acitretin. $J$ Am Acad Dermatol 60: 713-715. [Crossref]

232. Lee JY, Ok SJ, Oh CK, Park SK, Kim do W, et al. (2013) Spinal arteriovenous malformation masquerating zoster sine herpete. Korean J Pain 26: 72-75. [Crossref]

233. Kurihara Y, Inoue H, Kiryu H, Furue M (2012) Epithelioid hemangioma (angiolymphoid hyperplasia with eosinophilia) in zosteriform distribution. Indian $J$ Dermatol 57: 401-403. [Crossref]

234. Liss WA, Norins AL (1993) Zosteriform transient acantholytic dermatosis. J Am Acad Dermatol 29: 797-798. [Crossref]

235. Lee HJ, Jung KE, Kim HS, Lee JY, Kim HO, et al. (2014) Zosteriform transient acantholytic dermatosis. J Dermatol 41: 104-105. [Crossref]

236. Scholtz JR, Williamson C (1951) Vitiligo in apparent dermatomal distribution. AMA Arch Derm Syphilol 64: 366-369. [Crossref]

237. Park JH, Jung MY, Lee JH, Yang JM, Lee DY, et al. (2014) Clinical course of segmental vitiligo: a retrospective study of eighty-seven patients. Ann Dermatol 26 61-65. [Crossref]

238. van Geel N, Bosma S, Boone B, Speeckaert R (2014) Classification of segmental vitiligo on the trunk. Br J Dermatol 170: 322-327. [Crossref]

Copyright: $(02015$ Hayderi L. This is an open-access article distributed under the terms of the Creative Commons Attribution License, which permits unrestricted use, distribution, and reproduction in any medium, provided the original author and source are credited. 